Keywords: Abnormal hemoglobins, Hemoglobin G-Waimanalo, Hemoglobin Fontainebleau

Anahtar Sözcükler: Anormal hemoglobinler, Hemoglobin G-Waimanalo, Hemoglobin Fontainebleau

\section{Authorship Contributions}

Concept: Duran Canatan, Design: Duran Canatan, Data Collection or Processing: Serpil Delibaş, Gülsüm Yazıcı, Vildan Çiftçi, Analysis or Interpretation: Türker Bilgen, İbrahim Keser, Gülsüm Yazıcı, Vildan Çiftçi, Literature Search: Duran Canatan, Türker Bilgen, Writing: Duran Canatan.

Conflict of Interest: The authors of this paper have no conflicts of interest, including specific financial interests, relationships, and/or affiliations relevant to the subject matter or materials included.

\section{References}

1. Harteveld CL, Higgs DR. Alpha-thalassaemia. Orphanet J Rare Dis 2010;5:13.

2. Blackwell RQ, Jim RT, Tan $\mathrm{TG}$, Weng Ml, Liu CS, Wang CL. Hemoglobin G Waimanalo: alpha-64 Asp leads to Asn. Biochim Biophys Acta 1973;322:27-33.

3. Brennan SO, Chan T, Ryken S, Ruskova A. A second case of Hb Fontainebleau [alpha21(B2)Ala-->Pro] in an individual with microcytosis. Hemoglobin 2009;33:258-261.

4. Akar N. An updated review of abnormal hemoglobins in the Turkish population. Turk J Hematol 2014;31:97-98.

5. Lin M, Wu JR, Yang LY, Chen H, Wang PP, Wang Q, Zheng L. Hb G-Waimanalo: occurrence in combination with alpha-thalassemia-1 Southeast Asian deletion. Blood Cells Mol Dis 2009;42:36-37.

6. Tan TG, Jim RT, Blackwell RQ. Hemoglobin G Waimanalo beta thalassemia. Hawaii Med J 1978;37:235-239.

7. Lin $M$, Wang $Q$, Zheng L, Huang $Y$, Lin $F$, Lin CP, Yang LY. Prevalence and molecular characterization of abnormal hemoglobin in eastern Guangdong of southern China. Clin Genet 2012;81:165-171.

8. Wajcman H, Blouquit $Y$, Gombaud-Saintonge G, Riou J, Galacteros F.Hb Fontainebleau [alpha 21(B2)Ala----pro], a new silent mutant hemoglobin. Hemoglobin 1989;13:421-428.

9. Turner A, Sasse J, Varadi A. Hb Fontainebleau (HBA2: c. $64 \mathrm{G}>$ C) in the United Arab Emirates. Hemoglobin 2014;38:216-220.

\title{
Serum Lipids in Turkish Patients with $\beta$-Thalassemia Major and $\beta$-Thalassemia Minor
}

Türk $\beta$-Talasemi Majör ve $\beta$-Talasemi Minör Hastalarının Serum Lipidleri

\author{
Yasemin Işık Balcı1, Şule Ünal2, Fatma Gümrük ${ }^{3}$ \\ 1 Pamukkale University Faculty of Medicine, Department of Pediatric Hematology, Denizli, Turkey \\ 2 Hacettepe University Faculty of Medicine, Department of Pediatric Hematology, Ankara, Turkey \\ ${ }^{3}$ Hacettepe University Faculty of Medicine, Department of Radiology, Ankara, Turkey
}

To the Editor,

It is well-known that $\beta$-thalassemia is associated with changes in plasma lipids and lipoproteins $[1,2,3]$. To our knowledge, no data are available on lipid profiles in Turkish $\beta$-thalassemia major (TM) and $\beta$-thalassemia trait (TT) patients together. The aim of this study was to evaluate lipid profiles in two groups of patients with $\beta$-TM and $\beta$ - $\Pi$ and to compare them with healthy controls. The study included a total of 311 subjects. Group 1 included $131 \beta$-TM patients (mean age: $16.3 \pm 7.58$ years). Group 2 included $68 \beta$ - $\Pi$ patients (mean age: $7.25 \pm 4.43$ years). Group 3 consisted of 112 age- and sex-matched healthy controls (mean age: $9 \pm 4.7$ years). Serum ferritin level was $2487 \pm 1103$ (range: 661-5745) $\mathrm{ng} / \mathrm{mL}$ in Group 1. In comparing the correlation between ferritin and lipid parameters, while a significantly negative relationship was detected between ferritin and highdensity lipoprotein cholesterol (HDL-C) $(p=0.000, r=-0.602)$, a significantly positive relationship was detected between ferritin and triglyceride (TG) levels $(p=0.02)$ in TM patients. Serum lipid profiles of the 3 groups are shown in Table 1.

Previous studies have shown total serum cholesterol, HDL-C, lower low-density lipoprotein cholesterol (LDL-C), and higher TG in $\beta$-TM patients compared to healthy controls $[1,2,3]$. In our study, we found lower serum total cholesterol, lower HDL-C, LDL-C, and higher TG in $\beta$-TM patients compared to healthy controls. The pathophysiology of hypocholesterolemia in thalassemia remains obscure, although several mechanisms have been proposed; plasma dilution due to anemia, increased cholesterol requirement associated with erythroid hyperplasia, macrophage system activation with cytokine release, and increased cholesterol uptake by the reticuloendothelial system $[4,5]$. Previous studies reported different variations in lipid profiles of $\beta-\Pi$ patients $[6,7]$. In our study, we demonstrated 


\begin{tabular}{|c|c|c|c|c|c|c|}
\hline & \multirow{2}{*}{\begin{tabular}{|l|} 
Group 1 \\
$\beta$-TM $(n=131)$
\end{tabular}} & \multirow{2}{*}{\begin{tabular}{|l|} 
Group 2 \\
$\beta-\Pi(n=68)$
\end{tabular}} & \multirow{2}{*}{$\begin{array}{l}\text { Group } 3 \\
\text { Control }(n=112)\end{array}$} & \multicolumn{3}{|c|}{ p-values } \\
\hline & & & & Groups 1-2 & Groups 1-3 & Groups 2-3 \\
\hline T-Chol & $118.5 \pm 30.6$ & $145.6 \pm 27.6$ & $154.3 \pm 31.7$ & 0.00 & 0.00 & NS \\
\hline LDL-C & $59.1 \pm 27.6$ & $82.5 \pm 24.9$ & $89.6 \pm 26.1$ & 0.00 & 0.00 & NS \\
\hline HDL-C & $34.4 \pm 11.2$ & $45.7 \pm 12.2$ & $45.5 \pm 11.1$ & 0.00 & 0.00 & NS \\
\hline TG & $121.8 \pm 50.8$ & $82.9 \pm 34.6$ & $97.8 \pm 52.4$ & 0.00 & 0.00 & NS \\
\hline
\end{tabular}

similar lipid profiles in $\beta-\Pi$ patients and healthy controls. Based on statistical insignificance, we considered that the effects of lipid profile on the development of atherosclerotic vessel disease were similar in both $\beta-\Pi$ patients and the healthy control group. Serum iron and iron stores, expressed as elevated ferritin levels, have been implicated in coronary artery disease. Iron overload depletes the antioxidant and HDL-C levels. Lower HDL-C level is an important risk factor for development of coronary heart diseases [8]. We found significant relationships of serum ferritin levels with TG and HDL-C in $\beta$-TM patients. These results indicate that $\beta$-TM patients who need life-long red blood cell transfusions should receive chelation therapy not only for iron overload-induced congestive heart failure but also in order to prevent cardiovascular diseases resulting from lipid profile alterations.

In conclusion, lipid profiles of $\beta$-TM patients differed from those of $\beta$ - $\Pi$ patients and healthy controls. The present study demonstrates that lower levels of HDL-C in $\beta$-TM should be a reason for concern for better evaluation of the cardiovascular risk factors in $\beta$-TM. In order to reduce the effects of lipid metabolism on cardiovascular disorders, an effective chelating therapy is essential in TM patients.

Keywords: Thalassemia major, Thalassemia minor, Serum lipids

Anahtar Sözcükler: Talasemi majör, Talasemi minör, Serum lipidleri

\section{Authorship Contributions}

Concept: Yasemin Işık Balcı, Design: Yasemin Işık Balcı, Data Collection or Processing: Yasemin Işık Balcı, Şule Ünal, Fatma Gümrük, Analysis or Interpretation: Yasemin Işık Balcı, Şule Ünal, Literature Search: Yasemin Işık Balcı, Şule Ünal, Fatma Gümrük, Writing: Yasemin Işık Balcı.

Conflict of Interest: The authors of this paper have no conflicts of interest, including specific financial interests, relationships, and/ or affiliations relevant to the subject matter or materials included.

\section{References}

1. Maioli $M$, Vigna GB, Tonolo G, Brizzi $P$, Ciccarese $M$, Donega $P$, Maioli $M$, Fellin R. Plasma lipoprotein composition, apolipoprotein (a) concentration and isoforms in $\beta$-thalassemia. Atherosclerosis 1997:131;127-133.

2. Mansi KM, Aburjai TA. Lipid profile in Jordanian children with $\beta$-thalassemia major. Int J Hematol 2008;18:93-98.

3. Nasr MR, Abdelmaskoud AM, Abd El-Aal KS, Mabrouk NA, Ismael WM. Plasma lipid profile and lipid peroxidation in beta-thalassemic children. J Clin Lipidol 2008;2:405-409.

4. Papanastasiou DA, Siorokou T, Haliotis FA. $\beta$-Thalassaemia and factors affecting the metabolism of lipids and lipoproteins. Haematologia (Budap) 1996;27:143-153.

5. Hashemieh $M$, Javadzadeh $M$, Sihirkavand $A$, Sheibani K. Lipid profile in minor thalassemic patients: a historical cohort study. Bangladesh Med Res Counc Bull 2011;37:24-27.

6. Namazi MR. Minor thalassemia as a protective factor against cerebrovascular accidents. Med Hypotheses 2002;59:361-362.

7. Maioli M, Pettinato S, Cherchi GM, Giraudi D, Pacifico A, Pupita G, Tidore MG. Plasma lipids in $\beta$-thalassemia minor. Atherosclerosis 1989;75:245-248.

8. Brizzi $P$, Isaja T, D'Agata A, Malaguarnera L, Malaguarnera M, Musumeci S. Oxidized LDL antibodies (OLAB) in patients with $\beta$-thalassemia major. J Atheroscler Thromb 2002;9:139-144.
Address for Correspondence/Yazışma Adresi: Yasemin IŞIK BALCI, M.D.,

Pamukkale University Faculty of Medicine, Department of Pediatric Hematology, Denizli, Turkey

Phone : +90 5325477179

E-mail : dryibalci@gmail.com
Received/Geliş tarihi: April 26, 2015 Accepted/Kabul tarihi: August 17, 2015

DOI: $10.4274 /$ tjh.2015.0168 